\title{
Analysis on Income of Underemployed Women in Palembang South Sumatera
}

\author{
Bambang B. Soebyakto, Yunisvita, and Ita
}

\begin{abstract}
This paper attempt to analyze the income of women underemployment in Palembang. It discussed the factor those affecting revenue of underemployment in Palembang. The analysis technique used quantitative descriptive analysis. Statistical method used is regression with the dependent variable of income of women underemployment, and independent variable of extra income, husband's income and number of family members.

The data used in this study were primary data drawn from questionares distributed to underemployment women in the city of Palembang. The variable husband's income, additional extra income and number of family member partially had a significant effect on income of respondents.

It can be concluded that women underemployment wereable to adapt the conditions more when compare with the underemployed, with variety of reasons, among others: husband's income is more than sufficient to support the famil;y income, with work that is not so heavy women underemployment can keep control of the household activity in Palembang.
\end{abstract}

Index Terms-Underemployed women, age, extra income, number of family members, husband's income.

\section{INTRODUCTION}

Unemployment becomes a serious problem in economic development in Indonesia. It is also happened in South Sumatera province where Palembang as the mother city of it. The number of unemployment increased drastically from 2009 where only 8.14 percent as a whole of Indonesia, and in South Sumatera the number reached to 7.61 percent [1]. This number was increased not only in the number of unemployed people but also the number of people those categorized as job seekers. We can say as a classical opinian that because the growth of population does not followed by increasing of job opportunities [1].

In Palembang, the number of open unemployment in 2009 was 104,852 people or around 15.76 percent, it means that the number of people those really actively working was 559,808 people or 84.24 percent [1]. However, by those number of actively working people there are some of them who still categorized as people those working not suitable to their time or underemployed. The number of people those underemployed in Palembang was 89,335 people or 15.59 percent [1].

There are three group of workers those categorized as

Manuscript received February 28, 2016; revised April 30, 2016.

The authors are with the Faculty of Economics, Sriwijaya University, Indonesia (e-mail: yuditz@yahoo.com). underemployment [2], such as:

1) If they are working less than 40 hours in a week.

2) Someone who working full time but not receiving adequate income then seeking another an extra or additional job.

3) Someone whose his or her job is not suitable to the higher degree of schooling.

The case of underemployment becomes important because it is implicated to the growth of productivity, especially when compare between the productivity of people underemployment with those fully working [3].

The productivity growth of underemployment workers influenced by [3]:

1) Family and husband's income and, so if those to income higher it may cause women do not working full time.

2) The number of the family and responsibility of women in taking care of the whole family. We know that in many developing countries, many beliefs that extended family system which followed may influence many people in the family will take more responsibility in making money together. In the contrary, if the sense of responsibility within the family is lower then not all members of the family are going to seek a job.

3) Skill, training, and experience are useful to influence whether the members of the family will fully working or not.

Related to several reasons above, underemployment occured as follows, First: most married women working less than 40 hours, distributed their time to take care the family and work outside the house. Second, some of them who still in schooling shared their time both to work and continue their education. Third, some of them those lack of certain skill would stay home because they affraid of loss change to compete with other in seeking job [4].

This paper attempt to analize " how additional incomes, husband's earning and and family members to the income of underemployment women in Palembang, the mother city of South Sumatera province ".

\section{LITERATURE REVIEW}

\section{A. Undeeremployment}

A factor caused on the lower living standard in many developing countries is a limitation of industries or economy absorb or provides job opportunity [18], when compared with developed countries. Further, some reason appeared for those problems, First, underemployment in 
many jobs are still exist, it is always happened even in urban and rural areas, so most of them have no change to rise their productivity. Second, high number in open unemployment, there are people who are able to work but can not grap any job [5], [9].

There are three groups of people those classified as underemployment [6], Firstly, less in working time; Secondly, low income level. Then, if people those working but having of these classification means that they are not fully exploited by the circumstances. Thirdly, mismatch between occupation or job with the individual qualification [11].

Moreover, [6] also stated that labor market analysis based on the approach in labor utilization, are quite complicated and difficult to apply especially in many developing countries, because the measurement of labor utilizing always used the existing of unemployment and underemployment. However, most underemployment are always influenced by productivity and the income of labor [12]. Besides, in many developing countris, productivity and the labor income are still difficult to measure [13].

\section{B. Labor Analysis : Leisure time Choices}

Assumed there are two main categories which can make people happy; as leisure and goods. The combination of those two groups can create utility that may substitute each other in order to keep people still happy in life [7].

Leisure time and money can used to produce of utility. Workers allocated their leisue time to act of activity will increase of the workers income [12].

\section{Productivity Theory}

Productivity related the efficiency of input used to produce of output (goods and services). The worker productivity were determined by education (formal and infromal education). Based on education, the workers kwon and understand what will they do in the job [18]. The higher level of education, the workers quality will be higher too.

There are two reason why it is important to raise the labor productivity [8]. First, labor productivity incresing is fundamental resources increasing of wage. Second, increasing of life standard.

\section{RESEARCH METODOLOGY}

Research is done in Palembang on underemployment married women through the income of husband, additional earnings and the family members.

Table above shown that underemployment women are mostly spreaded in several sectors such as industry, wholesales (retail, restaurants and hotels) and services. Further, the high number of underemployment women is mostly concentrated in services sector (29,027 women) and wholesales (21,479 women).

By using the sample measurement of Slovin, this research should have used 200 women from wholesales and services sectors [15], [16] and [17]. However, since respondent are found by applying accidental sampling methods, and it is hard to seek women thse really working as underemployment, so this research used only 150 samples. Besides, accidental sampling method is one of the nonprobability sampling technique, where this method declared that not all member of population have same opportunity to be selected as a sample [10].

TABLE I: UNDEREMPLOYMENT WOMEN IN PALEMBANG

\begin{tabular}{|c|l|r|}
\hline No & \multicolumn{1}{|c|}{ Field of Business } & \multicolumn{1}{c|}{ Total } \\
\hline 1 & Agriculture, forestry, hunting and fishery & 2.096 \\
\hline 2 & Mining & 0 \\
\hline 3 & Industry & $\mathbf{4 . 8 5 3}$ \\
\hline 4 & Electricity, gas and water & 0 \\
\hline 5 & Buildings & 0 \\
\hline 6 & Wholesales, retail, restaurant and hotel & $\mathbf{2 1 . 4 7 9}$ \\
\hline 7 & Transportation, warehouses and communications & 1,087 \\
\hline 8 & Financial, insurance, etc & 390 \\
\hline 9 & Services & $\mathbf{2 9 . 0 2 7}$ \\
\hline & Total & 58.932 \\
\hline
\end{tabular}

(Source : National Labor Survey, 2010:26)

\section{A. Technique of Analysis}

Measurement in this paper used multiple regression as follows:

$$
Y_{i}=a+b_{1} X_{1 i}+b_{2} X_{2 i}+b_{3} X_{3 i}+e
$$

where:

$$
\begin{aligned}
& Y_{i}=\text { Income of Respondent to- } i \\
& X_{1 i}=\text { Husband's income to- } i \\
& X_{2 i}=\text { Additional income to- } i \\
& X_{3 i}=\text { Number of Family members to- } i \\
& a=\text { constant } \\
& b_{1-3}=\text { Regression coefficient } \\
& e=\text { error }
\end{aligned}
$$

\section{RESULT AND DISCUSSION}

Respondent chosen in this research are those finished a certain education level such as senior high alumni (77 workers), academy or diploma degree (42 workers) and university degree (31 workers). According to Sumarsono Someone will be working seriously if their degree on education is suitable to the job he or she found or get [5]. By this certain position, a worker is also serious in showing and increasing productivity.

Looking at the number of family members, most respondents have on average 3 to 6 members. More, the number of family members shown the welfare of the family. Then, the more bigger the number of the family members will influence whether some members will decide to find another jon in order to make an additional income. Number of family members of the respiondents as 28 women (19\%) have family between 1 to 2 people, 80 women $(53 \%)$ have family between 3 to 4 people and 42 women (28\%) heve more than 5 people.

Research was also found that most respondents are in a productive age as 20 to 40 years. Detail, 34 women (23\%) are around $20-25$ years, 50 women $(34 \%)$ are within age range of $26-30$ years. Based on respondent age, 38 women $(26 \%)$ are $31-35$ years. The 28 women $(17 \%)$ is between $36-40$ years.

Unfortunately, almost of fresh gradutes in the age 
between 20 to 25 years old workers from senior high school group of women, have no much experience in their first time working. The average montly income earned by respondents is in between one million to two million rupiahs or equivalent to US dollars is around $\$ 80$ to $\$ 160$. However, the women underemployment which are searched mostly working in less than 40 hours and all of them received income less than two million rupiahs. They received only one and half million rupiahs a month.

TABLE II: RESPONDENTS’ INCOME, HUSBAND’S INCOME AND ADDITIONAL INCOME

\begin{tabular}{|c|c|c|c|c|c|c|}
\hline Income & \multicolumn{2}{|c|}{$\begin{array}{c}\text { Respondents } \\
\text { Income }\end{array}$} & \multicolumn{2}{c|}{$\begin{array}{c}\text { Husband's } \\
\text { Income }\end{array}$} & \multicolumn{2}{c|}{$\begin{array}{c}\text { Additional } \\
\text { Income }\end{array}$} \\
\hline (Rupiahs) & Total & $\%$ & Total & $\%$ & Total & $\%$ \\
\hline $\begin{array}{c}\text { Less than } \\
1000.000\end{array}$ & 21 & 14,0 & 0 & 0,0 & 79 & 53,0 \\
\hline $\begin{array}{c}1.000 .000- \\
1.500 .000\end{array}$ & 82 & 54,0 & 0 & 0,0 & 47 & 31,0 \\
\hline $\begin{array}{c}1.600 .000- \\
2.000 .000\end{array}$ & 41 & 28,0 & 30 & 20,0 & 24 & 16,0 \\
\hline $\begin{array}{c}2.100 .000- \\
2.500 .000\end{array}$ & 6 & 4,0 & 47 & 31,0 & 0 & 0,0 \\
\hline $\begin{array}{c}\text { More than } \\
3.000 .000\end{array}$ & 0 & 0,0 & 73 & 49,0 & 0 & 0,0 \\
\hline Total & 150 & 100 & 150 & 100 & 150 & 100 \\
\hline
\end{tabular}

Source: Field Research Data, 2010

This table shown that most income of respondents are obtained caused of husband's income as 73 women or 49 percent. Underemployment women coudl increase their income by attending such specific woman training as skill courses as character building in terms of rising their income in the future. Furthermore, the ability in public service will be useful to get job in services sector. The increasing ability on this field increases efficiency and effectivity of workers.

The result of statitical measurement found much informations od data range, mean and standard deviation for 150 respondents, as followed below:

TABLE III: DATA RANGE, MEAN DAN STANDAR DEVIASI

\begin{tabular}{|c|c|c|c|}
\hline \multirow{2}{*}{ Variables } & \multicolumn{3}{|c|}{$n=150$} \\
\cline { 2 - 4 } & Range & Mean & $\begin{array}{c}\text { Std. } \\
\text { Deviasi }\end{array}$ \\
\hline Income of respondents & 22.00 & 58,2933 & 4.51031 \\
\hline Husband's income & 19.00 & 59,7867 & 3.69034 \\
\hline Additional income & 22.00 & 59,1800 & 3.90331 \\
\hline Number of the family & 63.00 & 60,7667 & 7.34337 \\
\hline
\end{tabular}

Source: Field research data processed, 2015

\section{A. Income $(Y)$}

Total income $(Y)$, as on data the above on average all respondents have the same income as seen 58,2933, with median 59,000 and mode 61.00 with standard deviation 4.51031 and minimum value is 47.00 where maximum value is 69.00 and total value is 8744 . Data showed that mean dan modus are not differentiated. So the frequency distribution of variable income tends to be normally distributed.

\section{B. Husband's Income $\left(X_{1}\right)$}

Based on data in Table $\mathrm{V}$, variable independent $\left(X_{1}\right)$ as husband's income, from 150 respondents it have an average rating of 59,7867 , median 60,0000 , mode 62,00 . The data shows that the average (mean) and the mode with the median is not much different. This illustrates the distribution of frequencies of the variable Income husband, Gaussian distribution data are likely to be.

TABLE IV: RESPONDENTS' INCOME $(Y)$

\begin{tabular}{|c|c|c|c|c|c|c|}
\hline \multicolumn{7}{|c|}{ Incoem N= 150 } \\
\hline Mean & Median & Mode & Strd.Dev & $\begin{array}{c}\text { Minimum } \\
\text { value }\end{array}$ & $\begin{array}{c}\text { Maximum } \\
\text { value }\end{array}$ & Sum \\
\hline 58 & 59 & 61 & 4.5 & 47 & 69 & 8744 \\
\hline
\end{tabular}

Source: Field research data processed, 2010

TABLE V: INCOME HUSBAND $\left(X_{1}\right)$

\begin{tabular}{|c|l|l|c|c|c|l|}
\hline \multicolumn{7}{|c|}{ Husbands Income N= 150 } \\
\hline Mean & Median & Mode & $\begin{array}{c}\text { Std } \\
\text { dev }\end{array}$ & $\begin{array}{c}\text { Minimum } \\
\text { value }\end{array}$ & $\begin{array}{c}\text { Maximum } \\
\text { value }\end{array}$ & Sum \\
\hline 59,7887 & 60,000 & 62,00 & 3,69034 & 48,00 & 67,00 & 8968 \\
\hline
\end{tabular}

Source: Field research data processed, 2010

\section{Additional Income $\left(X_{2}\right)$}

All data of additional income is complete, no defect, characterized the lack of any data missing. The data shows that the average (mean) and the mode with the median is not much different. This illustrates the distribution of frequencies of the variable Income distribution data tend to be Gaussian.

\begin{tabular}{|} 
TABLE VI: ADDITIONAL INCOME $\left(X_{2}\right)$ \\
\begin{tabular}{|c|c|c|c|c|c|c|}
\hline \multicolumn{7}{|c|}{ Additional Insome $\boldsymbol{N = 1 5 0}$} \\
\hline Mean & Median & Mode & $\begin{array}{c}\text { Std. } \\
\text { Deviation }\end{array}$ & $\begin{array}{l}\text { Minimum } \\
\text { value }\end{array}$ & $\begin{array}{l}\text { Maximum } \\
\text { Value }\end{array}$ & Sum \\
\hline 59,1800 & 60,000 & 61,00 & 3,90331 & 45,00 & 67,00 & 8877 \\
\hline
\end{tabular}
\end{tabular}

Source: Field research data processed, 2010

\section{Number of Family Members}

To find out the frequency distribution of the data variable the numbers of family can be seen in the following table:

All data about is complete, no defect, characterized the lack of any data missing. The data shows that the mean and the mode with the median is not much different. This illustrates the variable frequency distribution of the number of family members spread the data tends to be Gaussian.

TABLE VII: NUMBER OF FAMILY MEMBERS $\left(X_{3}\right)$

\begin{tabular}{|l|c|c|c|c|c|c|c|}
\hline Variable & \multicolumn{7}{|c|}{$N=150$} \\
\cline { 2 - 7 } & Mean & Median & Mode & $\begin{array}{c}\text { Std. } \\
\text { Dev }\end{array}$ & $\begin{array}{c}\text { Min } \\
\text { Value }\end{array}$ & $\begin{array}{c}\text { Max } \\
\text { value }\end{array}$ & Sum \\
\hline Membes & 60,7 & 61 & 62 & 7,343 & 51 & 114 & 9115. \\
\hline
\end{tabular}

Source: Field research data processed, 2010

Regression model is

$$
Y=35,949+0.210 \mathrm{HI}+0.108 \mathrm{AI}+0.056 \mathrm{FM}+\mathrm{e}
$$

where as

$\mathrm{HI}=$ Husband Income

$\mathrm{AI}=$ Additional Income

$\mathrm{FM}=$ Family Members

Variable of husband income, additional income and family member have positif direction that meaning the increasing of these variables will increase of the women underemployees income.

By simultaneous test, the level of signifcant is 0.048 . This significant is less than 0.05 , it means the husban 
income, additional income and family member have a positive and significant affect to women underemployees income in Palembang city.

Partially, the husband income, addiotional income and family members have a significant level as 0.039, 0.029 and 0.013. All variable have significant level less than 0.05 , it means that all variable partially have a positive and significant affect to women underemployees income in Palembang City.

\section{E. Husband Income}

Husband has a duty to meet the needs of family life. If the family's needs are met by the husband, the wife does not have to work for money. Due to the family's need can not be met by the husband's income, and then she needs to look for additional income to meet family needs such as a worker in the company, a housekeeper and became a shopkeeper in the market. With the operation of the wife, the family's needs will be met.

Wife works are not only caused by the lack of husband's income, but due to the wife's motive to have their own money to be used for other purposes, such as to the salon, travelling, and buying gold. The wife who has income, the wife has the freedom to spend your own money. In this condition, the husband's income is high, it will cause the wife compelled to have their own income, so that the relationship positive and significant.

The husband and wife have income would improve the welfare of the family, so that health and education will be a good family [14]. Their quality of life will also be getting better [7], [8].

\section{F. Additional Income}

The husban obligation to be earns an extra income so that their family's needs are met. Additional income can be earned by the husband after or before working hours at their place of work. Additional income can be obtained from motorcycle taxis; freelines worked at several companies, become security guards in the compound and opened small businesses at home.

Most families to earn extra income by opening a small business at home, such as selling children's food, food stalls, stalls basic material needs, tailor clothes, making crafts and printing.

Income from this business will be used to meet the needs of the family. In addition, it will reduce the family to buy snacks children.

These efforts, both by sumai or by the wife, would increase family income. The more extra income means more business husband and wife to earn money, so that is positive and significant influence on the wife's income.

\section{G. Family Members}

The number of families shows how many responsibilities to be met by the family. Total family consists of husband, wife, children and other people who live together in the family that are the responsibility of the family such as grandparents and nephews.

With more and more number of families, the husband's income is fixed, resulting in shortage of family income to meet their needs. In this case, the wife should have the initiative to earn an income. Income derived by a wife is used to meet the needs of family life. Income wife should be able to cover the shortfall husband's income. The more the husband's income shortfall caused by the number of families, it must increasingly wife's income. Thus, the number of families will be affected positively and significantly related to income that will be earned by the wife

\section{CONCLUSION AND REMARK}

\section{A. Conclusion}

Based on the results of the research and the discussion then it can be summed up as follows:

1) Husband income, extra income and the number of family members partially have significant effects to total income of respondent. On this research can be seen that the mating, female underemployed are more able to adapt to the conditions of the underemployed, for various reasons, among others: the husband's income is more than enough to support the family income, with jobs that are not so heavily courting female underemployed can keep controls the behavior of the household.

2) A large number of family members, influence mating female underemployed to find extra work to supplement the family's income because of the demands of the responsibility to meet the needs of living family members. The responsibility to improve the welfare of the family has an important role in increasing the family income.

3) Husband income, extra income, and the number of family members simultaneously have significant influence towards total income of women. The coefficient of determination $\left(\mathrm{R}^{2}\right)$ of $44.5 \%$, it means that the independent variable influeced of dependent variable $44.5 \%$ and while it is remaining $55.50 \%$ are influenced by other factors not included in this study.

\section{B. Suggestions}

Conclusion based on the results of the study as described previously, then the following section need to be given some advice to parties related to this study: the variables that affect total income of respondents take effect simultaneously then half unemployed women should be able to consider a third variable as a consideration in the decision to increase the total income of the respondent. With an increase in total income of respondents expected ability to sustain the purchasing power of families can be improved significantly. Therefore, half unemplyed women should do several steps as follows:

1) Reproduce a work in terms of hours doing additional work.

2) Have a capability to know the situation of the market to seek any extra work opportunities without having to rely on the income of the husband.

3) Further, to other researchers those interested in exploring research on this field must crack down their investigation by developing another free variables to explore the way how to increase the income of underemployed women, because there are more other variables that could be measured in order 
to broaden this reseach in the future.

\section{REFFERENCES}

[1] Badan Pusat Statistik (BPS). Sumatera Selatan Dalam Angka 2009. [Online]. Available: http//www.bps.go.id

[2] Dumairy, Perekonomian Indonesia, Jakarta, PT, Erlangga, 1999

[3] Bonnal, "Underemployment and local employment dynamics: New evidence," The Review of Regional Studies, vol. 39, no. 3, 2009.

[4] Matthews, Labor Discipline, Reputation and Underemployment Traps, Department of Economics Middlebury College, Middlebury Vermont, 2005

[5] M. P. Todaro, Pembangunan Ekonomi di Dunia Ketiga, Edisi Keenam, Edisi Terjemahan, Penerbit Erlangga, Jakarta, 1998.

[6] S. Sonny, Ekonomi Manajemen Sumberdaya Manusia dan Ketenagakerjaan, Yogyakarta: Penerbit Graha Ilmu, 2003.

[7] R. G. Ehrenberg and R. Smith, Modern Labor Economic, Pearson Education, Inc. United States of America, 2003.

[8] S. L. Bruce and D. Macpherson, Contemporary Labor Economics, International Edition, MacGray-Hill companies, Singapore, 1999.

[9] Sugiyono, Memahami Penelitian Kualitatif, Alfabeta, Bandung, 2005

[10] Neneng, Pola Konsumsi Rumah Tangga Setengah Menganggur Kasus Guru SDN di Kecamatan Ilir Barat 1 Kotamadya Palembang, Tesis, PPS Universitas Sriwijaya, Palembang, 2006.

[11] I. B. Mantra, Definisi, Dimensi dan Bentuk Pengangguran, Jakarta, 2009.
[12] Borjas and J. George, Labor Economics, Second Edition, Singapore, Mc.Graw Hill, International Edition, 1999.

[13] Bolliger, Measuring Underemployment at the Conty Level, Kentucky, 2003.

[14] F. Barceinas-Paredes, J. Oliver-Alonso, J. L. Raymond-Bara, and J. L. Roig-Sabaté, Bernhard A. Unemployment and Returns to Education in Europe, Working paper. Barcelona

[15] Emzir, Metodologi Penelitian Kualitatif, Analisis Data, PT Raja Grafindo Perkasa, Jakarta, 2010.

[16] J. Supranto, Statistik: Teori dan Aplikasi, Edisi ketujuh, Erlangga. Jakarta, 2008

[17] Kuncoro and Mudrajad, Metode Riset untuk Bisnis \& Ekonomi, Edisi 3, Erlangga, Jakarta, 2009.

[18] M, P. Todaro, Economic Development, Addison Wesley, New York, 2000 .

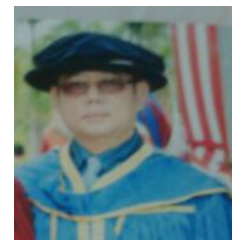

Bambang Bemby Soebyakto was completing an undergraduate at the Faculty of Economics, University of Sriwijaya. He recived his masters in economics at the University of Flinders Australian and $\mathrm{He}$ completing a doctorate in Northern University of Malaysia in the economic of human resources field. Bemby has be chairman of the master of economic studies program and now a serves as vice dean for student affairs. 